\title{
Solarization for Pest Management in Florida ${ }^{1}$
}

\section{Romy Krueger and Robert McSorley²}

\section{Solarization - How does it work?}

Solarization is a soil management practice that is typically carried out during the warm summer months to benefit crops grown in the following fall. It involves covering of soil with clear plastic, which is sealed into the soil around its edges and left in place for several weeks (Figure 1). Transparent plastic sheets allow short-wave radiation from the sun to penetrate the plastic. Once the light passes through the plastic and is reflected from the soil, the wavelength becomes longer and cannot escape through the plastic. The trapped light facilitates heating of the soil to temperatures detrimental to most living organisms. Most organisms in the soil are negatively affected by temperatures greater than $39-40^{\circ} \mathrm{C}\left(102-104^{\circ} \mathrm{F}\right)$ (Stapleton and DeVay, 1995). Temperatures under plastic can rise to $35^{\circ} \mathrm{C}$ to $60^{\circ} \mathrm{C}\left(95^{\circ} \mathrm{F}\right.$ to $\left.140^{\circ} \mathrm{F}\right)$ during the summer months (Katan 1981, Stapleton 1991) when air temperatures are close to $32^{\circ} \mathrm{C}\left(89.6^{\circ} \mathrm{F}\right)$ or higher. Soil temperatures only rise to detrimental levels in the upper 10 to $30 \mathrm{~cm}$ (3.9 to 11.8 in) of soil (Katan 1987), and even in this range temperatures drop off markedly as depth increases. Higher temperatures may be reached when solarization is conducted in greenhouses or in containers (Stapleton et al., 2000).

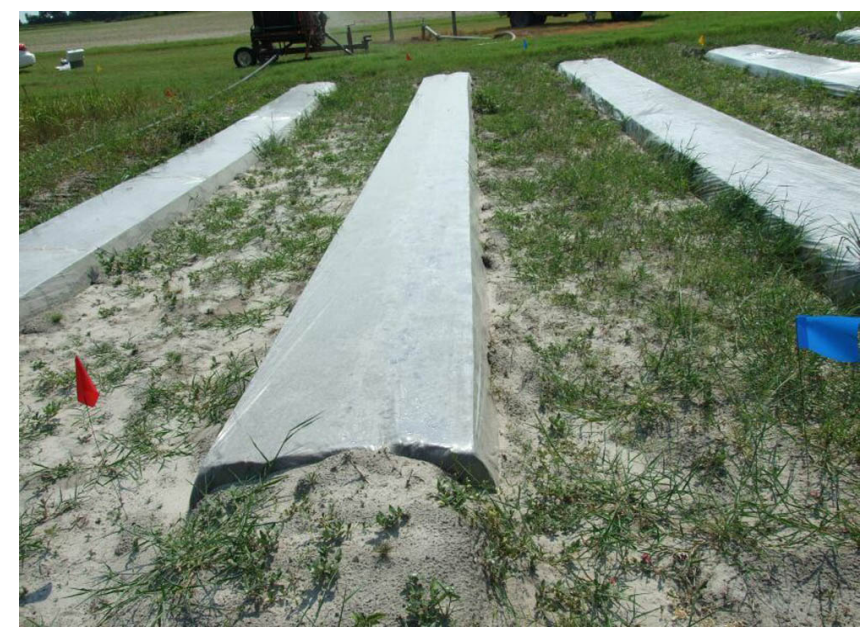

Figure 1. Planting beds covered with clear plastic film.

In a review by Rosskopf et al. (2005), solarization was considered one of the more promising non-chemical alternatives to methyl bromide, a broad-spectrum fumigant applied to commercial production sites to limit weed emergence, disease, nematode, and insect occurrence. Methyl bromide was often used as the standard to compare methods of pest, disease, and weed control, because it has been regarded as the most effective management tool against potentially harmful agents originating in soil. Because of involvement of methyl bromide in the depletion of the protective ozone layer as documented in the Montreal Protocol (Anonymous

1. This document is ENY-902 (IN824), one of a series of the Entomology and Nematology Department, Florida Cooperative Extension Service, Institute of Food and Agricultural Sciences, University of Florida. First printed: July 2009. Please visit the EDIS Website at http://edis.ifas.ufl.edu.

2. Romy Krueger, graduate assistant, and Robert McSorley, professor, Entomology and Nematology Department, Institute of Food and Agricultural Sciences, University of Florida, Gainesville, FL 32611.

The Institute of Food and Agricultural Sciences (IFAS) is an Equal Opportunity Institution authorized to provide research, educational information and other services only to individuals and institutions that function with non-discrimination with respect to race, creed, color, religion, age, disability, sex, sexual orientation, marital status, national origin, political opinions or affiliations. U.S. Department of Agriculture, Cooperative Extension Service, University of Florida, IFAS, Florida A. \& M. University Cooperative Extension Program, and Boards of County Commissioners Cooperating. Millie Ferrer, Interim Dean 
1998), its agricultural uses are being phased out (Anonymous 2009) and researchers have been looking for equally successful pest/disease management tools.

In the beginning, solarization in Florida was either carried out as broadcast solarization where the entire field was covered with clear or photoselective polyethylene plastic (Chellemi et al. 1994, Overman, 1985) or as raised bed solarization (Figure 1) where only the beds were covered with plastic film (McSorley and Parrado, 1986). Because many growers use raised beds and because soil temperatures reached under broadcast solarization can be $2^{\circ} \mathrm{C}$-to $4^{\circ} \mathrm{C}$ lower than under strip/raised bed solarization (Chellemi et al., 1997), the raised bed/strip solarization approach is now more often used in Florida.

Solarization affects all living organisms that are present in the upper $30 \mathrm{~cm}$ (11.8 in) of the soil. It can be used to manage weeds, diseases caused by soil-borne pathogens, and nematodes. Effectiveness of solarization can be somewhat variable when methyl bromide is the standard with which it is compared. Unfortunately a number of beneficial organisms are also negatively affected, especially bacterivores and fungivores (organisms that feed on bacteria and fungi and therefore aid in decomposition of soil organic matter). Following solarization, beneficial predators start to return by the end of the next growing season, whereas fumigation has longer-lasting effects (Wang et al. 2006). However, Ozores-Hampton et al. (2004) and Seman-Varner et al. (2008) showed that organic matter decomposition was not affected by solarization, so presumably the beneficial bacteria and fungi involved in decomposition recover quickly after solarization (also see the section below on soil nutrients).

\section{Technical Advice - Which plastic to use and application}

Different types of plastic sheets are available, mainly differing in their thickness (insulation) and ability to let light through (transparency). Black, opaque, or translucent plastics are not suitable for solarization, because instead of letting radiation pass through and heating the underlying soil, solar energy is absorbed and radiated back into the air and only slight warming of the covered soil occurs. Thin, transparent plastic sheets appear to achieve the best results. Katan (1981) recommended thicknesses between 25 to $30 \mu \mathrm{m}$ (1.0 to $1.2 \mathrm{mil}$ ). However, Chase et al. (1998) showed that thinner clear plastic $(19 \mu \mathrm{m})$ was more readily penetrated by purple nutsedge. This occurred even after transformation from rhizomes to leaves had already taken place. The plastic film may also have been in too close contact with the soil. Thicker clear plastic $(30 \mu \mathrm{m})$, IR retentive films $(100 \mu \mathrm{m})$, and bubble films (30 $\mu \mathrm{m})$, as well as thin plastic applied to the soil with a 5-10 $\mathrm{mm}$ air space decreased penetration. Additional research by Chase et al. (1999) supported the earlier suggestion that thermal-infrared retentive (TIR) film can consistently achieve higher soil temperatures (> $\left.45^{\circ} \mathrm{C}\right)$ than the thinner $(30 \mu \mathrm{m})$ low density polyethylene clear film and therefore was more efficient in managing soil-borne organisms, including weeds. High temperatures above $45^{\circ} \mathrm{C}$ are especially important in limiting invasion of planting beds by nutsedge, because of their tolerance to high temperatures. In addition, TIR films can achieve higher temperatures at greater soil depths, which will increase control success.

In general plastic films are applied in single layer. However, McGovern et al. (2002) used two sheets of 25-ìm clear, low-density polyethylene mulch separated by a $7.5-\mathrm{cm}$ air space to achieve better heat insulation.

Bed orientation can make a difference in the suppression of weeds. Weeds often emerge on the sides of the beds (Figure 2), because they are shaded and therefore soil temperatures cannot rise to detrimental levels. Beds orientated north-south had reduced weed emergence compared to east-west orientation (McGovern et al., 2004).

Before covering the soil with plastic, it should be watered to obtain moist soil. Moisture will render pathogens in the soil more sensitive to heat and also will ensure adequate heat conductivity (Katan, 1981). Mahrer et al. (1984) established that decreasing moisture levels resulted in reduced maximum temperatures achieved when using clear plastic polyethylene mulch. The plastic must be sealed 


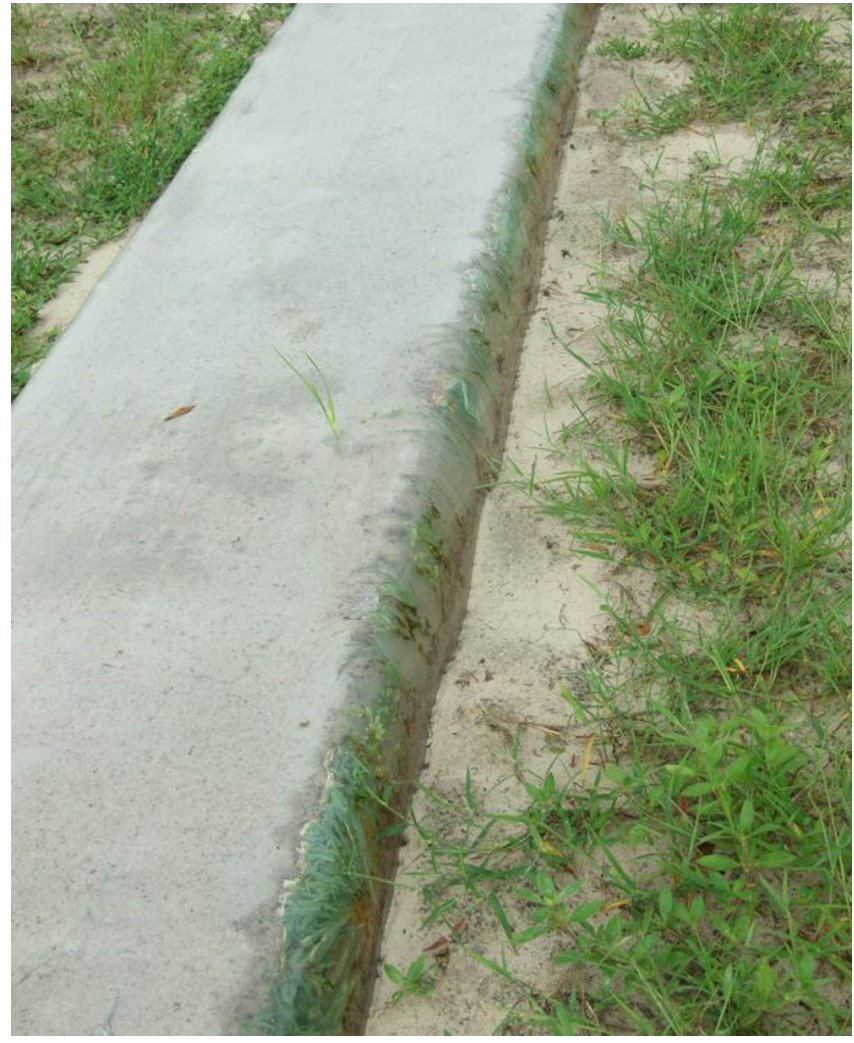

Figure 2. Weeds emerging on the side of the bed underneath the plastic.

(usually with soil) to prevent air movement underneath the plastic, which would prevent temperatures from rising sufficiently (Figure 3 ).

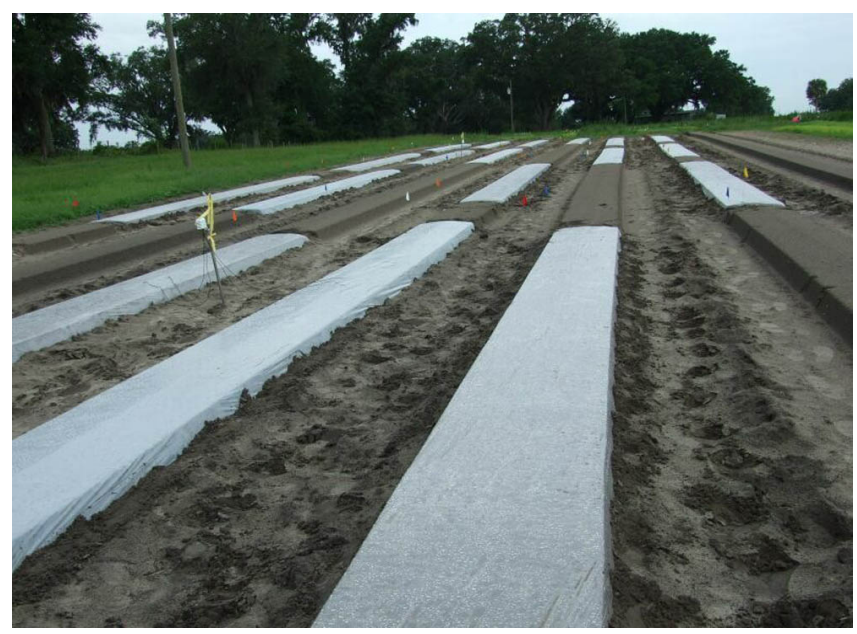

Figure 3. Plastic film sealed with soil.

The soil should remain covered for a minimum of four to six weeks, but increasing solarization time improves effectiveness. This helps to heat the soil at a greater depth, which means that more nematodes will be affected (McGovern and McSorley 1997). Furthermore it also ensures that an adequate accumulation of solarized hours (hours in which sun was present) is achieved, which is important in regions like Florida where the sky is often overcast during the summer months.

\section{Affected Organisms}

\section{Nematodes}

Plant-parasitic nematodes are killed by high temperatures. Early research on Meloidogyne javanica (root-knot nematode) showed that movement of juveniles stopped immediately after being exposed to $50^{\circ} \mathrm{C}$ and there was no recovery even after returning the temperature to $25^{\circ} \mathrm{C}$. Lowering the temperature resulted in longer periods required to kill juveniles; at $42^{\circ} \mathrm{C}$ it required 3 hours (Wallace 1966). In Tanzania, egg masses of $M$. javanica were buried in soil (15-cm depth) and exposed to solarization. Within two to three weeks, all eggs were dead. Soil temperatures under solarization reached an average of $43^{\circ} \mathrm{C}$, with maximum of $45^{\circ} \mathrm{C}$ (Madulu and Trudgill 1994).

Solarization can be effective in Florida, but may be impaired by overcast skies and rainfall during the warmest summer months. In order to counteract these effects, the solarization time could be prolonged. Increasing the length of solarization will cause mortality based on the accumulation of sub-lethal, but detrimental temperatures. McGovern et al. (2000) solarized soil for 41 days mainly during October in southwest Florida, which resulted in the reduction of awl (Dolichodorus heterocephalus) and stubby-root (Paratrichodorus minor) nematodes. Nematodes were exposed to average maximum temperatures of $38.4,33.6$, and $29.8^{\circ} \mathrm{C}$ at depths of 5,15 , and $23 \mathrm{~cm}$. A recent laboratory study confirms that nematodes can be affected by an accumulation of sub-lethal temperatures (Wang and McSorley, 2008). Eggs and juveniles of Meloidogyne incognita were exposed to a series of temperatures from 38 to $45^{\circ} \mathrm{C}$. At 44 and $45^{\circ} \mathrm{C}$, juveniles were killed within one hour. For lower sub-lethal temperatures, the hours required for suppression decreased with increasing temperatures (Table 1). Success of solarization depends on maximum temperatures reached in the field. The higher the temperature, the shorter the duration of solarization required to kill nematodes. Temperatures 
over $40^{\circ} \mathrm{C}$ should be the goal in order to shorten the solarization period. In a 6 -week solarization period (Florida: July to August), temperatures high enough to kill nematodes could be accumulated (Wang and McSorley, 2008).

Table 1. Hours needed to kill $100 \%$ of Meloidogyne incognita eggs and juveniles.

\begin{tabular}{||c|c|c||}
\hline \hline Temperature $\left({ }^{\circ} \mathrm{C}\right)$ & \multicolumn{2}{|c||}{ Hours to kill 100\% } \\
\cline { 2 - 3 } & Eggs & Juveniles \\
\hline 38 & 389.8 & -- \\
\hline 39 & 164.5 & 47.9 \\
\hline 40 & 32.9 & 46.2 \\
\hline 41 & 19.7 & 17.5 \\
\hline 42 & 13.1 & 13.8 \\
\hline \multicolumn{2}{|r|}{} \\
\hline Source: Wang and McSorley (2008). \\
\hline
\end{tabular}

Several nematodes species were negatively affected by solarization. It was effective in reducing populations of $M$. incognita, $D$. heterocephalus, $P$. minor, Belonolaimus longicaudatus (sting), Criconemella spp. (ring), and Roytlenchulus reniformis (reniform) (Chellemi et al. 1997; McGovern et al. 2002, McSorley and McGovern 2000, McSorley and Parrado 1986; Ozores-Hampton et al., 2004). However Chellemi et al. (1997) and Chellemi (2006) reported that they were unable to reduce Meloidogyne spp. and $R$. reniformis. In some cases, solarization was able to suppress populations of $M$. incognita or $R$. reniformis initially, but numbers recovered at the end of the cropping season (McSorley and McGovern, 2000; McSorley and Parrado, 1986). In addition, when using strip solarization, it is possible that fast recolonization of plant-parasitic nematodes may occur, because row middles (occupying up to $50 \%$ of the field) will remain untreated, although this late-season recovery may not limit overall yield (Chellemi et al., 1997).

Resurgence of certain nematode species may occur to higher levels than before solarization. The stubby-root nematode $P$. minor increased in numbers following three weeks of solarization (McSorley and McGovern, 2000). A possible explanation for resurgence could be that some nematode species have population reservoirs in deeper soil layers that are larger than those found in the upper soil layers. This unusual vertical distribution in soil often occurs with stubby-root nematodes. Although solarization reduces or eliminates these nematodes in the upper layers, recolonization can occur quickly by drawing upon a population pool from deeper soil layers. Similar resurgence of stubby-root nematodes has also been observed when these nematodes are managed with soil fumigation (Weingartner et al., 1983).

\section{Diseases}

Soil solarization can decrease the incidence and effects of disease-causing organisms that originate in the soil. Solarization for 47-48 days in September-October in west-central Florida either reduced disease frequency or slowed disease progression of crown rot and blight caused by Rhizoctonia spp. and root rot caused by Pythium spp. when a double layer of low polyethylene mulch was used (McGovern et al., 2002). In another case, solarization with a single layer of plastic mulch was more effective than methyl bromide in limiting an epidemic from Pythium spp. in a pepper field (Saha et al., 2005). In contrast, Chellemi (2006) failed to show a difference between white plastic mulch and clear plastic mulch in the suppression of Pythium spp. Incidence of phytophthora blight (Phytophthora capsici) was reduced by solarizing for 6-8 weeks (Chellemi 2006). Furthermore, densities of Phytophthora nicotianae and Ralstonia solanacearum were reduced by solarization in soil depths down to $25 \mathrm{~cm}$ (9.8 in) (Chellemi et al. 1994). Southern blight (Sclerotium rolfsii) and Fusarium wilt (Fusarium oxysporum f.sp. lycopersici) can also be substantially reduced with solarization and results are comparable to a methyl bromide control (Chellemi et al., 1997), but effects may be limited to the upper soil layer (Chellemi et al. 1994). Jones and Overman (1986) recommended solarization as one of the methods to manage Verticillium wilt (Verticillium albo-atrum). Several studies have concluded that bacterial wilt caused by $R$. solanacearum is not controlled by solarization (Chellemi et al. 1993, 1994, 1997). 


\section{Weeds}

Solarization can minimize weed emergence by causing thermal death to weed seeds. Solarization performed for 1-4 weeks reduced emergence of prickly sida (Sida spinosa), pigweed (Amaranthus spp.), morningglories (Ipomoea spp.), horse purslane (Trianthema portulacastrum), and several grass species (Egley 1983). Solarization is also an important tool to manage nutsedge (Johnson et al. 2007), which is often hard to control with regular mulches, because it grows as a rhizome (not requiring sunlight) until it encounters light, then pierces mulches with its sharp growing point and thereafter expands its leaves above the plastic film. Given sufficiently high solarization temperatures, purple and yellow nutsedges either do not emerge at all, or if they do emerge, then leaf expansion, which is stimulated by sunlight, will occur under the clear plastic, which will mostly prevent puncturing of the plastic. The plant will be exposed to the heat underneath the plastic and thermal death occurs (Chase et al., 1998) (Figure 4).

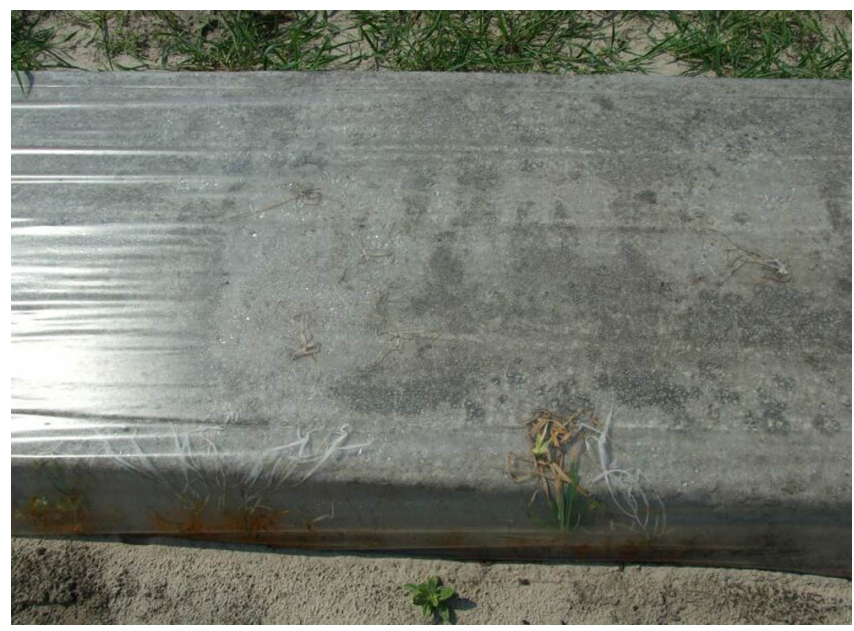

Figure 4. Thermal death of emerging nutsedge underneath clear plastic.

However, prolonged use of solarization can lead to a shift in weed populations when used as a long-term, single solution to weed management. In a study by Ozores-Hampton et al. (2004), beds that were treated with methyl bromide were dominated by pigweed (Amaranthus retroflexus), whereas solarized beds were primarily colonized by bermudagrass (Cynodon dactylon), a perennial that is harder to control by solarization than the annual pigweed.

\section{Integrating soil fertility and solarization}

\section{Soil Nutrients}

In general, availability of some nutrients can be expected to increase with solarization, because the heat generated under clear plastic will encourage accelerated decomposition of organic matter. In a field study in southwest Florida, soil nutrients were not affected by solarization compared to conventional treatment with methyl bromide (Ozores-Hampton et al. 2004). Solarization coupled with compost increased soil nutrient levels more than treatments with methyl bromide or solarization alone, both of which were combined with inorganic fertilizer. Seman-Varner et al. (2008) measured nutrient concentration in the soil and plant tissue of an okra crop following different durations of solarization. While soil potassium $(\mathrm{K})$ and manganese $(\mathrm{Mn})$ were higher following solarization, Copper $(\mathrm{Cu})$ and zinc $(\mathrm{Zn})$ were lower. In addition, soil $\mathrm{pH}$ was slightly decreased by solarization. Soil phosphorus $(\mathrm{P})$, magnesium $(\mathrm{Mg})$, calcium $(\mathrm{Ca})$, and iron $(\mathrm{Fe})$ were not affected by solarization. Nutrients supplied to the crop were exclusively provided by chopped cowpea hay. Okra tissue concentrations of K, nitrogen (N), $\mathrm{Mg}$, and $\mathrm{Mn}$ were higher when grown on solarized plots. In contrast, concentrations of $\mathrm{P}$ and $\mathrm{Zn}$ were lowered by solarization. Solarization increased okra biomass; the longer the duration of solarization, the greater the increase in okra biomass (based on comparison among 2-, 4-, and 6-week solarization periods). The positive yield response indicated that solarization did not impair organic matter decomposition and subsequent release of plant nutrients. Both of these studies (Ozores-Hampton et al., 2004; Seman-Varner et al., 2008) suggest that solarization does not interfere much with beneficial soil organisms that decompose organic matter.

\section{Integration}

Organic amendments may increase the effectiveness of solarization against pests (Gamliel and Stapleton 1993, Ozores-Hampton et al. 2004, Wang et al. 2006). Wang et al. (2006) showed that following a cowpea cover crop with solarization was more effective than solarization alone. In fact, the 
effectiveness of this combined treatment was comparable to methyl bromide fumigation.

Cabbage residues may or may not improve solarization success. When cabbage residues were incorporated as large undecomposed pieces, solarization was not improved and the cabbage may have served as a reservoir for diseases (Chellemi et al. 1997). However, grinding cabbage into powder and mixing it uniformly into the soil may improve solarization efforts (Gamliel and Stapleton, 1993).

\section{Considerations/Drawbacks}

The main disadvantage of solarization is its potential negative impact on beneficial soil microorganisms, since they will meet the same fate as their harmful counterparts. But recovery is usually attained quickly through rapid recolonization, because beneficial microorganisms appear better suited to utilize substrate and nutrients freed by solarization than their harmful counterparts. Furthermore, many beneficials such as Bacillus, Pseudomonas, and Trichoderma are able to survive the high temperatures generated by solarization. In addition, during the short time in which beneficial organisms have a competitive advantage over pathogenic and parasitic organisms, a population shift large enough to suppress these detrimental organisms may occur, limiting their recolonization (Katan 1987, Stapleton and DeVay 1995, Stapleton 2000). Solarization adversely impacts omnivorous nematodes, but their recovery is faster following solarization than following fumigation with methyl bromide (Wang et al. 2006).

Solarization generates considerable plastic waste, which is a major shortcoming if objectives are to reduce use of petroleum-based materials or to recycle agricultural materials. Some types of plastic sheets may break up into small fragments, which can make recycling even more difficult (Figure 5). Research is needed to develop biodegradable plastic films that are comparable to conventional clear plastic films in their ability to manage soilborne agents interfering with plant health. Possibly the clear plastic could be painted to be used as horticultural mulch during crop maturation (Chellemi et al., 1997).

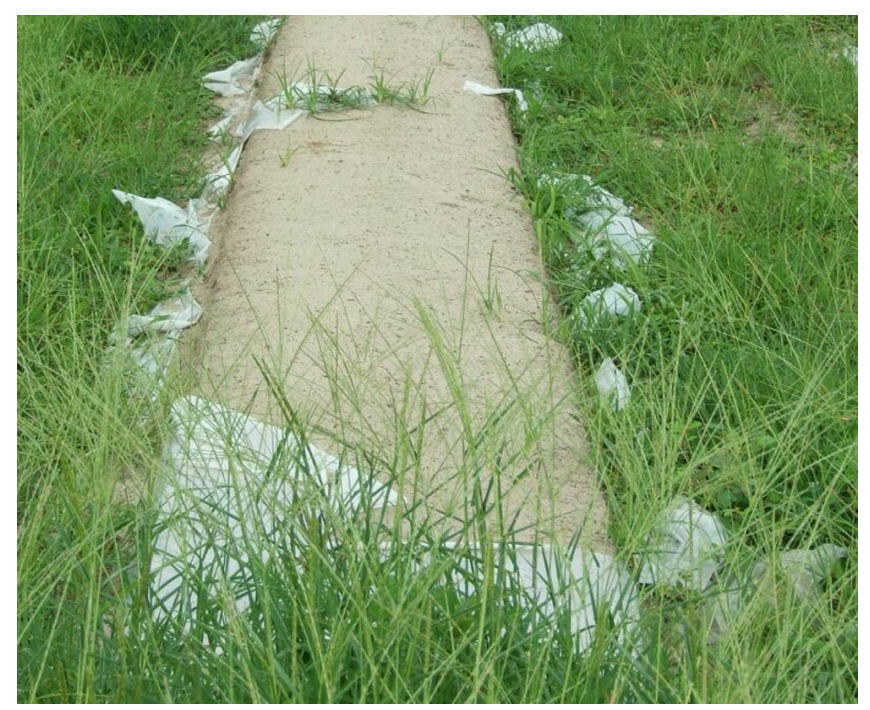

Figure 5. Breakdown of plastic film caused by prolonged sun exposure.

Although Florida has hot summers (high air temperatures), they are often characterized by overcast skies and high humidity and precipitation, which limits solar radiation and may diminish the success of solarization (DeVay 1991, Katan 1980). However solarization appears mostly to be successful in Florida, if unfavorable weather and solarization period do not coincide. Saha et al. (2007) successfully used solarization in Florida in 2003 and 2004 (starting July for 6 weeks) for managing pests and improving pepper yields. Maximum temperatures at a soil depth of $5 \mathrm{~cm}$ reached $\geq 42^{\circ} \mathrm{C}$ on $\geq 29$ days in both years. At a depth of $15 \mathrm{~cm}$, average maximum temperatures of $\geq 42^{\circ} \mathrm{C}$ were reached for fewer days than at 5 -cm depths. In contrast, temperatures in non-solarized plots rarely reached $42^{\circ} \mathrm{C}$ even at the 5-cm depth (0 days in 2003, 2 days in 2004). Chellemi et al. (1997) also concluded that although precipitation may occur on up to $64 \%$ of the solarization days, yields and disease/pest control can still be comparable to a methyl bromide standard. In contrast, Wang et al. (2004) were unable to show plant-parasitic nematode suppression under persistent cloudy weather conditions. Solarization was ineffective because of prolonged overcast skies for most of the solarization period. This resulted in lower soil temperatures than anticipated (usually $<40^{\circ} \mathrm{C}$ ), which affected nematode control and led to heavy emergence of weeds, especially nutsedges. This failure of solarization resulted from prolonged shading and limited exposure to direct sunlight. However, the many successful uses of solarization in 
Florida suggest that afternoon rain showers may not limit the procedure. Days with rainstorms may not be limiting to solarization provided that some clearing occurs and allows several hours of direct sunlight.

Evidence for this comes from bed orientation experiments in which weeds on edges of beds that were shaded much of the day were killed by a few hours of direct sunlight (Figure 6) (McGovern et al., 2004).

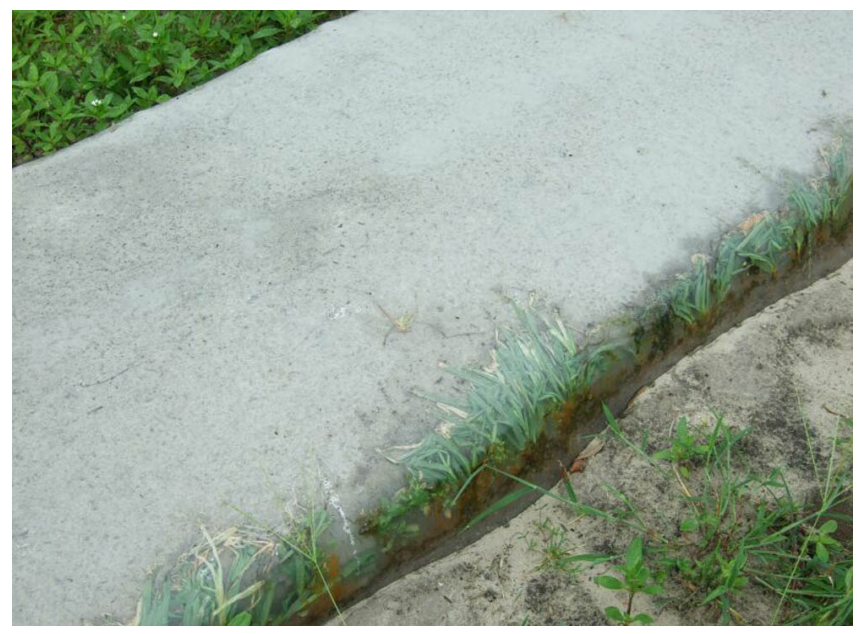

Figure 6. Weeds emerging on shaded side of the bed.

Small holes in the plastic may also reduce soil temperature. They can be caused by animals, especially birds, but can also be a sign of breakdown of the plastic film caused by UV radiation. Different plastic films may have different durabilities when exposed to solar radiation.

Although research has been conducted with materials other than single-layer polyethylene films (double-layer films for example), these films are not the norm. Although they may offer some benefits, they are commonly not used, because these films can be difficult to obtain or to apply with reasonable manpower, time, and economic resources. Therefore single-layer plastic films have been used in most studies carried out in Florida.

\section{Summary}

Soil solarization is the heating of soil under clear plastic, usually for 6 weeks or more. The edges of the plastic are sealed into the soil so that heat builds up and does not escape. The method can be used on beds, flat ground, or even for containers and small portions of soil. Solarization can be used for managing a variety of soil-borne problems, including weeds, plant-parasitic nematodes, and soil-borne diseases. In Florida, solarization is typically conducted during the summer months, and then the clear plastic is removed prior to planting fall and winter crops. Yields may be improved following pest management by solarization, although pest numbers typically recover by the end of most vegetable and ornamental crops. Results can vary depending on the pests present, type of plastic, application methods and materials, and weather conditions. Highlights of research results from Florida are summarized for a variety of different kinds of pest problems and situations.

\section{References}

Anonymous. 1998. Montreal Protocol on Substances that Deplete the Ozone Layer. United Nations Environmental Program (UNEP). http://www. epa.gov/spdpublc/mbr/mbtoc98.pdf.

Anonymous. 2009. The phaseout of methyl bromide. U.S. Environmental Protection Agency. http://www.epa.gov/Ozone/mbr.

Chase, C.A., Sinclair, T.R., Shilling, D.J., Gilreath, J.P., and Locascio, S.J. 1998. Light effects on rhizome morphogenesis in nutsedges (Cyperus spp.): implications for control by soil solarization. Weed Science 46:575-580.

Chase, C.A., Sinclair, T.R., and Locascio, S.J. 1999. Effects of soil temperature and tuber depth on Cyperus spp. Weed Science 47:467-472.

Chellemi, D.O. 2006. Effect of urban plant debris and soil management practices on plant parasitic nematodes, Phytophthora blight and Pythium root rot of bell pepper. Crop Protection 25:1109-1116.

Chellemi, D. O., Olson, S. M., and Mitchell, D. J. 1994. Effects of soil solarization and fumigation on survival of soilborne pathogens of tomato in northern Florida. Plant Disease 78:1167-1172.

Chellemi, D.O., Oslon, S.M., Mitchell, D.J., Secker, I., and McSorley, R. 1997. Adaptation of soil solarization to the integrated management of soilborne pests of tomato under humid conditions. Phytopathology 87:250-258. 
Chellemi, D. O., Olson, S. M., Scott, J. W., Mitchell, D. J., and McSorley, R. 1993. Reduction of phytoparasitic nematodes on tomato by soil solarization and genotype. Journal of Nematology 25:800-805.

DeVay, J.E. 1991. Historical review and principles of soil solarization, Ch. 2, In: Soil Solarization, Eds. DeVay, J.E., Stapleton, J.J., Elmore, C.L. FAO Plant Production Paper 109, FAO, Rome.

Egley, G.H. 1983. Weed seed and seedling reductions by soil solarization with transparent polyethylene sheets. Weed Science 31:404-409.

Gamliel, A., and Stapleton, J. J. 1993. Characterization of antifungal volatile compounds evolved from solarized soil amended with cabbage residues. Phytopathology 83:899-905.

Johnson III, W.C., Davis, R.F., Mullinix Jr., B.J. 2007. An integrated system of summer solarization and fallow tillage for Cyperus esculentus and nematode management in the southeastern coastal plain. Crop Protection 26:1660-1666.

Jones, J.P., and Overman, A.J. 1986. Verticillium wilt (race 2) of tomato. Plant Pathology Circular No. 284, Division of Plant Industry, Fla. Dept. Agric. \& Consumer Serv., Gainesville, FL.

Katan, J. 1980. Soil pasteurization of soils for disease control: status and prospects. Plant Disease 64: 450-454.

Katan, J. 1981. Solar heating (solarization) of soil for control of soil borne pests. Annual Review of Phytopathology 19:211-236.

Katan, J., 1987. Soil solarization. In: Innovative Approaches to Plant Disease Control, Ed. Chet, I. Wiley, New York, NY. pp. 77-105.

Madulu, J.D., and Trudgill, D.L. 1994. Influence of temperature on the development and survival of Meloidogyne javanica. Nematologica 40:230-243.

Mahrer, Y., Naot, O., Rawitz, E., and Katan, J. 1984. Temperature and moisture regimes in soils mulched with transparent polyethylene. Soil Science Society of America Journal 48:362-367.
McGovern, R. J., McSorley, R. 1997. Physical methods of soil sterilization for disease management including soil solarization, Ch.12, In:

Environmentally safe approaches to crop disease control, Eds. Rechcigl, N.A. and Rechcigl, J.E. CRC Lewis Publishers, Boca Raton, FL. pp. 283-313.

McGovern, R. J., McSorley, R., and Urs, R. R. 2000. Reduction of Phytophthora blight of Madagascar periwinkle in Florida by soil solarization in autumn. Plant Disease 84:185-191.

McGovern, R. J., McSorley, R., and Bell, M. L. 2002. Reduction of landscape pathogens in Florida by soil solarization. Plant Disease 86:1388-1395.

McGovern, R.J., McSorley, R., and Wang, K.-H. 2004. Optimizing bed orientation and number of plastic layers for soil solarization in Florida. Soil and Crop Science Society of Florida Proceedings 63:92-95.

McSorley, R., and McGovern, R.J. 2000. Effects of solarization and ammonium amendments on plant-parasitic nematodes. Supplement to the Journal of Nematology 32:537-541.

McSorley, R., and Parrado, J.L. 1986. Application of soil solarization to Rockdale soils in a subtropical environment. Nematropica 16:125-140.

Overman, A.J. 1985. Off-season land management, soil solarization and fumigation for tomato. Soil and Crop Science Society of Florida Proceedings 44:35-39.

Ozores-Hampton, M., McSorley, R., Stansly, P.A., Roe, N.E., and Chellemi, D.O. 2004 Long term large scale soil solarization as a low-input production system for Florida vegetables. Acta Horticulturae 638:177-188.

Rosskopf, E.N., Chellemi, D.O., Kokalis-Burelle, N., and Church, G.T. 2005. Alternatives to methyl bromide: A Florida perspective, APSnet Feature, June 2005. <http://www.apsnet.org/online/feature/ methylbromide/> accessed 07-23-2008.

Saha, S.K., McSorley, R., Wang, K.-H., and McGovern, R.J. 2005. Impacts of extreme weather 
and soil management treatments on disease development of Pythium spp. in field grown pepper. Proceedings of the Florida State Horticultural Society 118:146-149.

Saha, S.K., Wang, K.-H., McSorley, R., McGovern, R.J., and Kokalis-Burelle, N. 2007. Effect of solarization and cowpea cover crop on plant-parasitic nematodes, pepper yields, and weeds. Nematropica 37:51-63.

Seman-Varner, R., McSorley, R., and Gallaher, R.N. 2008. Soil nutrient and plant responses to solarization in an agroecosystem utilizing an organic nutrient source. Renewable Agriculture and Food Systems 23:149-154.

Stapleton, J.J. 1991. Thermal inactivation of crop pests and pathogens and other soil changes caused by solarization, Ch. 3, In: Soil Solarization, Eds. DeVay, J.E., Stapleton, J.J., and Elmore, C.L. FAO Plant Production Paper 109, FAO, Rome.

Stapleton, J.J. 2000. Soil solarization in various agricultural production systems. Crop Protection 19:837-841.

Stapleton, J.J., and DeVay, J.E., 1995. Soil solarization: A natural mechanism of integrated pest management. In: Novel Approaches to Integrated Pest Management, Ed. Reuveni, R. Lewis Publishers, Boca Raton, FL. pp. 309-322.

Stapleton, J.J., Prather, T.S., Mallek, S.B., Ruiz, T.S., and Elmore, C.L. 2000. High temperature solarization for weed control in container soil and potting mixes. Proceedings of the California Weed Science Society 52:204-207.

Wallace, H.R. 1966. Factors influencing the infectivity of plant parasitic nematodes. Proceedings of the Royal Society of London. Series B, Biological Sciences 164:592-614.

Wang, K.-H., McGovern, R.J., McSorley, R., and Gallaher, R.N. 2004. Cowpea cover crop and solarization for managing root-knot and other plant-parasitic nematodes in herb and vegetable crops, Soil and Crop Science Society of Florida Proceedings 63:99-104.
Wang, K.-H., McSorley, R., and Kokalis-Burelle, N. 2006. Effects of cover cropping, solarization, and soil fumigation on nematode communities. Plant and Soil 286:229-243.

Wang, K.-H., and McSorley, R. 2008. Exposure time to sub-acute lethal temperatures for Meloidogyne incognita suppression and its implication for soil solarization. Journal of Nematology 40:7-12.

Weingartner, D. P., J. R. Shumaker, and G. C. Smart, Jr. 1983. Why soil fumigation fails to control potato corky ringspot disease in Florida. Plant Disease 67:130-134. 